\title{
設計情報・意図を伴う設計プロセス支援のための統合モデル*
}

（第 1 報, 統合モデルの基本アーキテクチャ)

$$
\begin{aligned}
& \text { 竹 内 - 博*1, 妻 屋 彰*2 } \\
& \text { 若 松栄 史 }{ }^{* 2} \text {, 荒 井栄 司*2 }
\end{aligned}
$$

\section{Integrated Model for Computer Aided Design Process with Design Information and Intention (1st Report, Basic Architecture of Integrated Model)}

\author{
Kazuhiro TAKEUCHI*3, Akira TSUMAYA, \\ Hidefumi WAKAMATSU and Eiji ARAI \\ ${ }^{* 3}$ Fujitsu info Software Technologies Ltd. \\ 18-1 Minami-cho, Shizuoka-shi, Shizuoka, 422-8572 Japan
}

\begin{abstract}
In recent years, $3 \mathrm{D}-\mathrm{CAD}$ system has been rapidly improved However, the principal improvements are focused on the shape modeling and operativeness, so that it is still remained solved how to treat the design information and the intention generated within the design process. It is important for $3 \mathrm{D} \mathrm{CAD}$ to become means of more widely used infomation transmission and to support the designer to detailed design with design information and intention which was considered in the conceptual design. In this paper, we discuss the integrated model of the geometric model and the design information. In order to support the design process, the basic transmission architecture of the design information and intention is proposed.
\end{abstract}

Key Words : Design Information, Design Intention, Geometric Model, CAD, Design Process

\section{1. 背 景}

近年，自動車・航空機業界に閉じず，一般機械市場 においても三次元 CAD が普及してきている.しかし ながら, 最近の動向を見ると, 基本的には詳細設計に フォーカスした形状処理および操作性向上に着目した 進展が多い. 設計行為を支援する上で, CAD システ ムが設計情報・意図を扱うことは非常に重要である. 三次元 CAD システムは, 依然としていくつかの課題 を持っている(1)(2).

(1) 統合されていない.

・設計プロセスの状態を理解していない.

・設計上流の支援がない.

(2) 知的支援がない.

・設計者の意図を理解できない。

・設計知識, 設計者の常識を持っていない.

(3) 弱い $\mathrm{HCI}$ (Human Computer Interaction)

・効果的な誤り検出能力に欠ける.

* 原稿受付 2004 年 7 月 6 日.

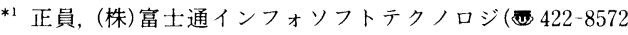
静岡市南町 18-1)

*2 正員, 大阪大学大学院工学研究科( $\mathbb{E} 565-0871$ 吹田市山田 丘 2-1)

E-mail : takeuchi@ist.fujitsu.com
・すべての情報を入力しなければならない.

これらの諸課題を解決するために，多くの研究がな されている．例えば，設計上流支援の問題では，

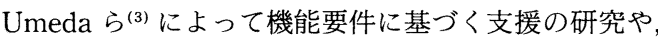
劉ら(4)(5)によって設計上流で重要な定性的な情報の扱 いについての研究が行われている．また，設計者の意

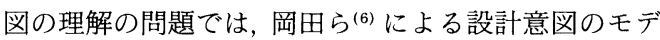
ル化や, Arai ら(7)らによる機能に着目した意図と幾 何モデルとの関連付けによる設計支援の研究が行われ ている.

これらの設計支援・設計意図情報のモデル化研究 は，設計上流段階に焦点を当てたものであり，CAD な どを利用して詳細設計段階までどのように設計情報・ 意図を伝達し, 利用させるかといった問題については まだ解決されていない.

われわれの目的は，概念設計を含む各設計工程で考 察された設計情報・意図が, 詳細設計段階でも正確に 有効に利用されるための要件・システムアーキテクチ ヤを提案することである。

本論文では，抽象的・具体的を問わず設計者によっ て設定された設計情報が, CAD システムが持ついか なる編集処理が行われても，その設定意図に従って正 確に後工程に伝達されるための要件を考察し，設計工 
程を支援するアーキテクチャの提案および特徴につい て述べる.

\section{2. 目的と要 件}

多くの設計においては，始めに製品全体の概要決定 を行い, 段階的に詳細化していく設計プロセスを経 る.このような設計プロセスにおいて, 設計上流で決 定した設計情報・意図が正確に下流設計に伝達されて いくことは，設計プロセスを支援するうえで重要であ る. 特に製品が複雑でチームで設計する場合は非常に 重要になってくる.

議論に入る前に, 本論文で想定している設計上流の イメージについて述べる。ここでは, 図 1 に示すよう な, 製品全体の全体的なレイアウト概要が決まった段 階を想定している。この段階では, 幾何形状は非常に 単純であり, 線, 面, 単純なソリッドなどで構成され ているが, 少なくとも幾何形状が存在している状態を 想定している。

以降において, 正確に情報を伝達するための基本要 件について述べる。

設計活動の中でさまざまな考察が行われ，最終的な 製品が設計される，最終的な製品は，形状および各種 の設計情報からなり,さまざまな意図のもとに決定さ れたものである。

設計上流から下流まで, 設計情報・意図を伝達して いくために，まず CAD システムが設計情報・意図を 形状モデルと統合された形で扱えるようにすることが 重要であると考える．その考察の意図，考察した情報 の設定および継承による, 設計情報・意図の後工程へ の伝達および再利用効果を図ることが重要であるから である。

設計情報・意図が詳細設計段階においても有効に活 用されるためには, 以下の要件を満たす必要がある.

（a）設定された設計情報・意図が，各種の編集が行 われても正確に継承されること。

（b）編集が行われた場合に，意図により設計情報固 有のふるまいが定義できること.

（c）情報の対象・内容が，できるだけ直感的にわか りやすいこと.

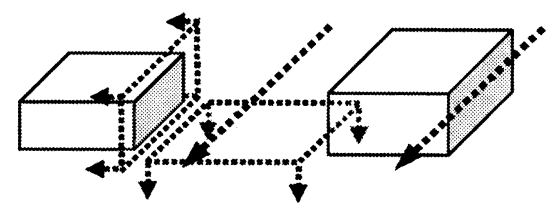

Fig. 1 Example of the initial stage image まず(a)については, 一般的にCAD システムが持 つ形状編集操作 (削除, 移動, 分割, マージ, 変形, 切 断など）が行われても，設定されている設計情報が正 確に伝達されていくことを意味している。ここでいう 正確とは，意図を反映した正確性である。これについ ては，（b）の説明で述べる，基本的には，設計情報が 設定された幾何要素の編集時に正確に編集後も設計情 報が伝達されることを意味するが，さらに設計情報が 設定された幾何要素を利用して, 他の幾何要素を編集 した場合の情報の伝達も重要である。

（b）については，同じ設計情報であっても意図によ り編集時にシステムの動作が異なるべきであることを 意味している. システムの動作には, 大きく 2 種類存 在する、第一は，本来の目的である設計情報の伝達方 法に関する動作であり，第二は伝達方法決定に伴う， 利用者へのシステムのリアクションに関する動作であ る.これらのシステムの動作をふるまいと呼ぶことと する，設計情報によっては，編集内容により意味のな くなる情報である場合や, 編集そのものを許さない情 報もありうる，以下は，設計情報の伝達について考慮 すべき例である。

（1）それぞれ異なる表面粗さ情報が設定されてい る 2 枚の面がマージされ 1 枚の面になった場合，表面 粗さなる設計情報の継承はどのように行うのが良いの か.

（2）材質と表面粗さ情報など, 密接に関係する設 計情報が設定されていた場合，材質の変更に伴い，表 面粗さは意味をなさなくなる場合や変更をしなければ ならない場合が考えられる。

（3）二つの面間に平行なる設計情報が設定されて いた場合に，片方の面に平行でなくなるような操作が 行われた場合を想定する.システムとして，この操作 を無効にすべきケースもあれば, 注意を喚起するだけ で操作を実行し平行なる設計情報を削除するケース， あるいは拘束条件のように他方の面を平行が維持され るように編集する場合も考えられる。

同じ設計情報が設定されていても，設定した意図に より伝達方法が異なるべきことを表している.

最後に（c）は, システムの利用しやすさの意味を表 している，設計情報・意図の設定および確認が容易に 行えることである.

\section{3. 基本アーキテクチャ}

3 章では, 2 章で述べた重要な要件について考察し, 各設計工程で設定された設計情報・意図が正確に伝達 されていくための基本アーキテクチャについて述べ 
る.

\section{$3 \cdot 1$ 状態変化を正確に把握するための考察}

$\mathrm{CAD}$ システムが基本的に扱う情報は形状である。 この形状を追加・変更していくプロセスにおいて, 設 計意図/設計情報が考察されている，したがって，設 計情報・意図が設定される対象として，モデル・形状 要素・寸法などを考察するのは，幅公い情報を扱うう えでの基本と考える.

$\mathrm{CAD}$ システムに対する基本的な指示は, 形状変更 に代表される形状付加/変更・寸法設定/変更等であ る.このような編集機能は多岐にわたり今後ともに増 加していくが，根本的に編集を受ける個々の要素に着 目すると, 各対象の変化を感知することで, 状態の変 化を正確に把推できる。表 1 は，設計情報・意図の設 定対象，および各対象に対して感知すべき変化種を表 した例である。

緃列の対象は, CAD システムが持っている生成あ るいは編集の単位を表している。横列の変化種は，シ ステムが持つ各種の編集機能を表している．表 1 中の ○部分に対する刘象と変化種をシステムが感知すべき であることを意味している，例えば，面に対しては， システムが值変吏の機能以外を持っていることによ り, 值変更以外はすべて○になっている.

このように, システムが持つ各種の対象に対して, どのような変化があったかを完全に感知することで, 状態の変化を正確に把握することが可能になる，基本 的に対象を変更するのはシステムであり，対象と変化 を把握することはシステム化するうえで容易である。

いままで述べてきたことは，基本的に幾何的情報の 変化に関するものである．設計対象をシステムで編集 していく場合に, 当然設計情報自身の内容変更が想定 される. 接合対象の変更, 表面粗さの変更, など設計

Table 1 Example of target and the types of change

\begin{tabular}{|c|c|c|c|c|c|c|c|c|}
\hline $\begin{array}{l}\text { Xype of } \\
\text { change } \\
\text { Target }\end{array}$ & 氶 & ס્: & 豙 & 浠 & 禀 & 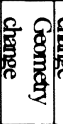 & 产 & 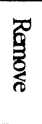 \\
\hline Model & - & - & $\overline{\mathrm{O}}$ & $\mathrm{O}$ & $\mathrm{O}$ & - & - & $\mathrm{O}$ \\
\hline Feature & - & - & $\mathrm{O}$ & $\mathrm{O}$ & $\mathrm{O}$ & - & - & $\mathrm{O}$ \\
\hline Face & $\mathrm{O}$ & $\mathrm{O}$ & $\mathrm{O}$ & $\mathrm{O}$ & $\mathrm{O}$ & $\mathrm{O}$ & - & $\mathrm{O}$ \\
\hline Edge & $\mathrm{O}$ & $\mathrm{O}$ & $\mathrm{O}$ & $\mathrm{O}$ & $\mathrm{O}$ & $\mathrm{O}$ & - & $\mathrm{O}$ \\
\hline Surface & - & - & $\mathrm{O}$ & $\mathrm{O}$ & $\mathrm{O}$ & $\mathrm{O}$ & - & $\mathrm{O}$ \\
\hline Curve & - & - & $\mathrm{O}$ & $\mathrm{O}$ & $\mathrm{O}$ & $\mathrm{O}$ & - & $\mathrm{O}$ \\
\hline $\begin{array}{l}\text { Anrangement } \\
\text { Constraint }\end{array}$ & - & - & - & - & - & - & $\mathrm{O}$ & $\mathrm{O}$ \\
\hline Dimension & - & - & - & - & - & - & $\mathrm{O}$ & $\mathrm{O}$ \\
\hline Work & - & - & $\mathrm{O}$ & $\mathrm{O}$ & $\mathrm{O}$ & $\mathrm{O}$ & - & $\mathrm{O}$ \\
\hline
\end{tabular}

情報に対する変更も頻繁に行われるものである。した がって, 設計情報自身を対象として扱えることおよび 変更されたことをシステムが感知することが重要とな る.

これは, 設計情報を設計情報の設定対象とすること である，設計情報は，データとして定義されており， システム内において一意的な識別子を持って管理され ている。したがって，一意的な識別子を持った設計情 報の変化をシステムが感知すること, すなわち設計情 報を対象化することは容易であり，設計情報の対象化， すなわちモデル化が可能になる.

$3 \cdot 2$ 幅広い設計情報を扱うための考察 幾何形 状に対する精度情報などは, 典型的な設計情報の一つ である。これらの設計情報には，単独の要素に対する 設計情報と要素間の関係に対する設計情報がある，表 面粗さ, 平面度などは, 前者であり, 平行度・同軸度 などは後者の例である。

したがって，設計情報定義の枠組を考察する場合に， 単独の要素に対する設計情報と, 要素間に関する設計 情報を扱うことが必須である，以降本論文では，単独 の要素に対する設計情報を単体設計情報, 要素間の関 係に対する設計情報を関係設計情報と呼ぶこととす る. 表 2 にこれらの精度情報についてまとめたものを 示す.

$3 ・ 1$ 節で述べたように, 設計情報の設定対象はモデ ル, 面, 稜線などシステムが生成・編集できる対象で ある. したがって, 単体設計情報は, モデル, 面, 寸法 などすべての単独の対象に対する設計情報である．モ デルの材質, 面の表面粗さなどである. 一方, 関係設

Table 2 Accuracy information

\begin{tabular}{|c|c|c|c|c|}
\hline & \multicolumn{2}{|c|}{ Accuracy Information } & \multicolumn{2}{|c|}{ Target Element } \\
\hline \multirow{6}{*}{ 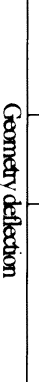 } & Shrme & Straightmess & $\begin{array}{l}\text { Edge, Plane, } \\
\text { Cylindrical }\end{array}$ & Single \\
\hline & SIlape & Cylindricity, etc. & $\begin{array}{l}\text { Free form } \\
\text { surface/wire }\end{array}$ & $\begin{array}{l}\text { Single/ } \\
\text { Relational }\end{array}$ \\
\hline & Posture & $\begin{array}{l}\text { Parallelism } \\
\text { Perpendicularity, } \\
\text { etc. }\end{array}$ & $\begin{array}{l}\text { Edge, Plane, } \\
\text { Centerime }\end{array}$ & \multirow{4}{*}{ Relationa } \\
\hline & \multirow{3}{*}{ Positional } & Location level & $\begin{array}{l}\text { Edge, Plane, } \\
\text { Cylindrical }\end{array}$ & \\
\hline & & $\begin{array}{l}\text { Coaxiality } \\
\text { Concentricity }\end{array}$ & Center axis & \\
\hline & & Symmetry & $\begin{array}{l}\text { Vertex, Edge, } \\
\text { Center axis }\end{array}$ & \\
\hline \multicolumn{3}{|c|}{ Surface roughness } & Face & Single \\
\hline \multicolumn{3}{|c|}{ Dimension Tolerance } & $\begin{array}{l}\text { Vertex, Edge, } \\
\text { Center axis }\end{array}$ & \multirow{2}{*}{ Relational } \\
\hline \multicolumn{3}{|c|}{ Angle Tolerance } & $\begin{array}{l}\text { Edge, Plane, } \\
\text { Center axis. }\end{array}$ & \\
\hline \multicolumn{3}{|c|}{ Fitting } & $\begin{array}{l}\text { Cylindrical, } \\
\text { Parallel planes }\end{array}$ & $\begin{array}{l}\text { Single/ } \\
\text { Relational }\end{array}$ \\
\hline
\end{tabular}


計情報もシステムが生成・編集できる対象間の設計情 報である，モデル間の結合情報，面間の平行などであ る.

\section{$3 \cdot 3$ 意図に基づくふるまいの考察＼cjkstart設計情報が} 設定されている対象が編集された場合に, 意図に基づ いてシステムの異なる動作が定義できることは重要で ある、なぜなら，同じ内容の設計情報であっても，設 計情報の伝達方法は異なり，必ず遵守すべき情報の場 合や, 参考として・目安としての情報などさまざまで あるからである。

例えば, 図 2 は, 左図の状態から右図の状態に幾何 情報を変化させる操作が行われた場合の例を表してい る．左図に示す二つの穴の軸に同軸なる設計情報が存 在した場合に, 右図に変化させる操作が行われたと仮 定する。この場合に，システムの動作は意図により異 なるべきである。あるケースでは, システムはこのよ うな操作を拒否すべきであるし，ある場合にはこの操 作を実行し設計情報を消去すべきである。

システムの動作は大きく二つに分類され，一つは編 集内容に依存した設計情報の取扱い方，他方は設計情 報の取扱い方に応じた操作の拒否，実行，アラーム， 通知などの意図の反映による設計者への注意の喚起の ための動作である.

このような状態変化に伴うシステムの動作が設計情
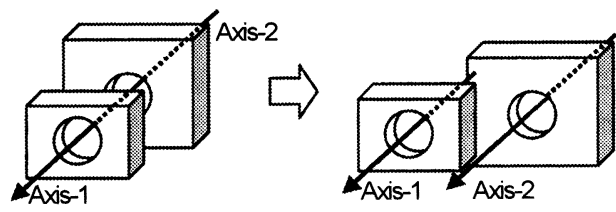

Fig. 2 Example of geometry change

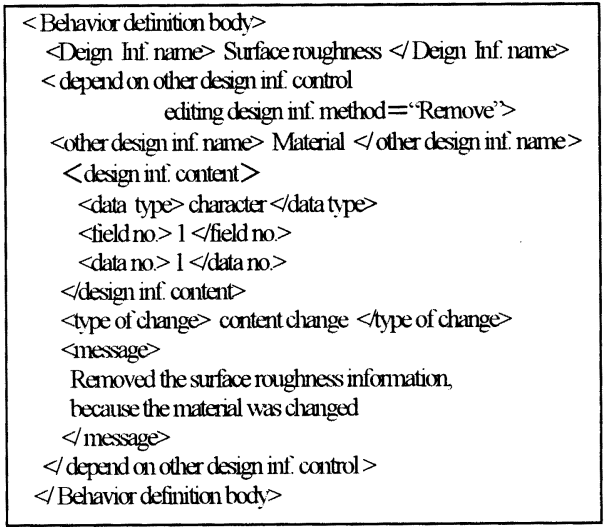

Fig. 3 Example of the behavior definition for the single design information (remove)
報とは独立して定義できることによる，意図を反映す る枠組が重要である。

このシステムの動作を定義する方法として，ふるま い定義体を導入する．ふるまい定義体において，ある 種の評価を可能にし, 評価結果に基づきシステムの動 作(設計情報の伝達方法, システムのリアクション)を 記述可能にする.

どのような評価に基づきシステムの動作を定義して いくべきかについて，3・2 節で述べた単体設計情報に 対するふるまい定義体と関係設計情報に対するふるま い定義体について以下に述べる。

$3 \cdot 3 \cdot 1$ 単体設計情報のふるまい定義体 個々の 要素に対する設計情報に関するふるまい定義体につい て述べる。

前述したように，設計情報に対する意図をシステム 動作に反映するためには，ふるまい定義体を柔軟に定 義できることが重要である．このために，本考察では 大きく三つの観点の情報を評価することによる，ふる まい決定を提案する。

（1）編集情報

いちばん基本となる各要素の変更状態(平行移動, 外形変更, 設計情報内容変更など) の情報

（2） 設計情報值

実際の設計情報が値を持つ場合の值(例：精度情報 など)

\section{（3）要素特性値}

各要素が持つマスプロパティおよび, 特別なべクト ル(例：平面の法線, 円筒の軸など)

これらの三つの情報に対して，值のあるものについ ては等号, 不等号による条件付けを可能にしたふるま いの定義方法を提案する。下記に単体設計情報のふる まい定義体例を示す。なお，本研究ではXML に準拠 した定義体記述方法を採用している。

図 3 は, 編集情報の評価による例であり，材質と表 面粗さ情報が設定されているモデルの材質が変更され た場合に，表面粗さ情報の削除を行い，メッセージを 出力して設計者に変更を知らせる動作定義例である.

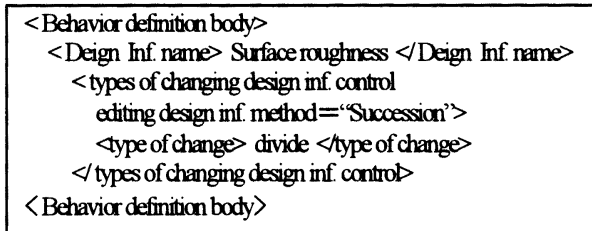

Fig. 4 Example of the behavior definition for the single design information (sucession) 
これは, 密接な関係のある設計情報間において, 設定 意図を反映した設計情報伝達が制御できることを示し ている.

また, 図 4 は対象要素が分割された場合に双方に同 じ設計情報を設定する動作の定義例である.

上記の二つの例は, 編集内容に依存して各々の設計 情報の伝達の方法(削除, 継承など)を定義できること で, 意図に応じた正確な情報伝達を可能にしているこ とを示している. 特に, 図 3 のように設計情報間の意 味合いを含めて設計情報の伝達を行うことが可能にな つている.

$3 \cdot 3 \cdot 2$ 関係設計情報のふるまい定義体 先に述 ベたように, 関係設計情報は, 要素間の関係に対する 設計情報を扱うための概念である．典型的な例として は, 精度情報の同軸度などが要素間情報である. 図 5 は, 関係設計情報管理に関するイメージ図である，本 例は, face-A と face-B が接するという関係情報の管 理イメージである.

関係設計情報は, 一般には要素群間の関係であり, 編集結果は組合せであり, 単体設計情報に比べ複雑に なる.また, 特性值も各々の特性值に加えて, 特性值 の組合せがある. したがって, 評価する情報種は単体 設計情報と同じ 3 種に加えて, 要素間に関する関係 值・特性値がある.

これらの四つの情報に対して, 值のあるものについ ては等号, 不等号による条件付けを可能にしたふるま いの定義方法を提案する.

（4）要素間関係値・特性值

いずれも要素間の空間的な相対的位置関係を把握す るための情報である.

・要素間干渉関係情報

干涉, 接触, 無干涉

- 要素間干涉関係値

干涉体積, 接触面積, 最短距離

- 特性値間の計算

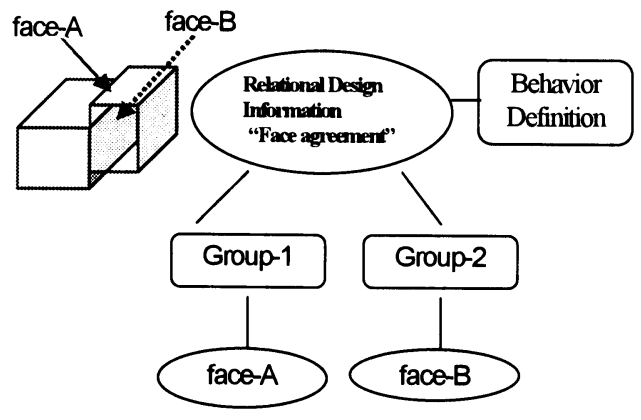

Fig. 5 Relational design information image
例：各要素の特徴点, ベクトルについての一致, 平 行, 垂直の関係

図 6 に, 基本的な特性値間計算例を示す.

図 7 の関係設計情報のふるまい定義体は，要素間干 涉関係である接触面積を比較する定義例であり，加工 対象であるワークの固定の方法として吸引による吸着 処理を設計情報として設定した場合に，接触面積をあ る範囲で満たさなければならない設計例で必要になっ たものである．本例のように，数值データを用いて， 制約条件としての利用も可能である.

また，図 8,9 の関係設計情報のふるまい定義体は， 編集情報の評価による例であり，面間の結合に関する 設計情報に対して, 削除以外の編集時には設計情報を 継承し, 幾何デー夕変更(面の形状が変化) 時に, 他方 の面の変更を促すメッセージ出力を表すふるまい定義 体例である、これは, 設計情報の意味を反映した設計 情報伝達が制御できることを示している。

\section{4. 基本アーキテクチャの考察}

3 章で提案した, 正確な変化の把握, 単体設計情報, 関係設計情報，およびふるまい定義体について，それ らのシステム化・動作イメージについて述べ, 設計情

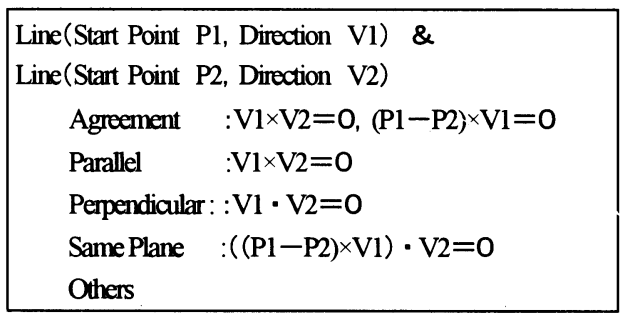

Fig. 6 Example of calculation between characteristic vectors

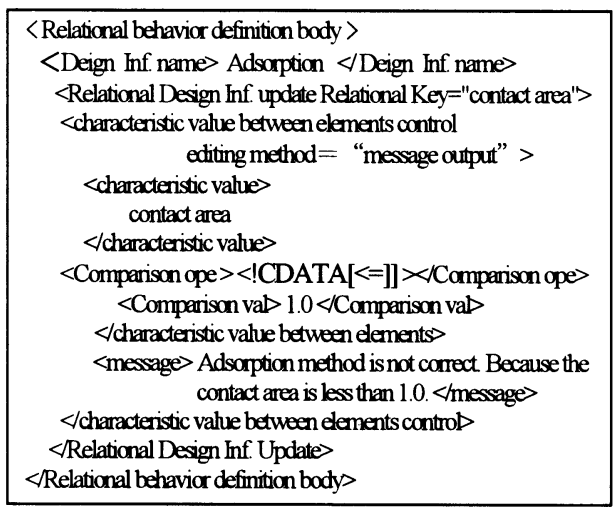

Fig. 7 Example of behavior definition for evaluating the adsorption area 
報・意図の伝達の枠組について説明する。

さらに，提案したアーキテクチャの考察を行い，そ の特徴について述べる.

$4 \cdot 1$ 実験システム概要 まず，前提となる形状 処理に関しては, 一般的に商用システムが持つ機能を 搭載し，ワイヤ〜ソリッド，解析曲面〜自由曲面を扱 えるシステムである.

また, 単体の部品〜アセンブリーまで扱えるシステ ムとする。したがって, 表 1 亿記述されている対象群 が想定される. 図 10 にコンポーネント概要図を示す. 図 10 に示す設計情報処理部は, 設計情報・意図を扱 うために新しく導入したコンポーネントである.

設計情報処理部は，図 11 に示すように，主に以下の サブコンポーネントからなる.

各サブコンポーネントの概要は以下である.

・ふるまい定義体

要素の変更内容に対応したシステム動作を記述した 定義体

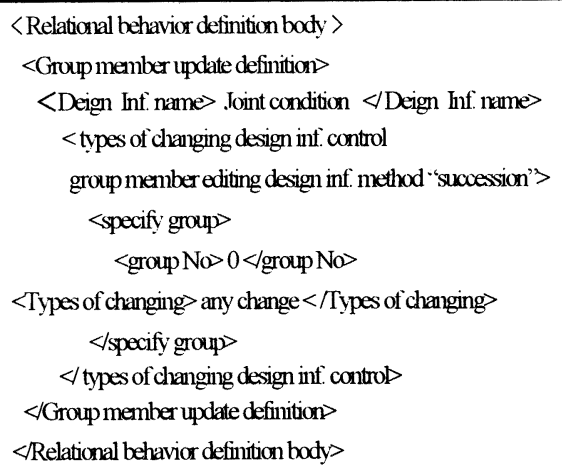

Fig. 8 Example of behavior definition for evaluating the adsorption area

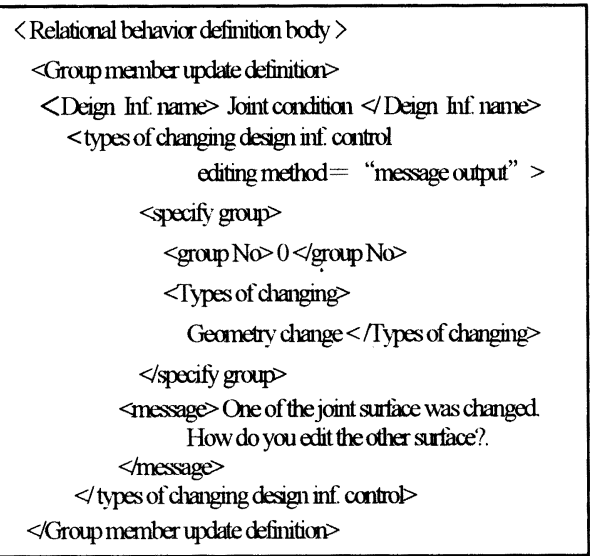

Fig. 9 Example of behavior definition
・ふるまい読取り部

ふるまい定義体デー夕の読取り部

・要素 ‘編集状態’検出部

各対象要素の変化状態を検出する処理部

・ふるまい判定部

ふるまい定義体の解釈，および編集状態などから， システムの動作を決定する処理部

・メンテナンス処理部

システム動作決定に伴うメンテナンス処理部

実際にモデル $\alpha \cdot \beta$ 間に図 8,9 のふるまい定義体 が定義され， $\alpha$ に面の張替えなど面の幾何データが変 更された場合の処理の流れは以下のようになる.

Step 1：要素 ‘編修状態’ 検出部がモデル $\alpha$ の面の幾何 データが変更されたことを感知する.

Step 2：モデル $\alpha$ に関係する設計情報およびふるまい 定義に対して下記処理を行う.

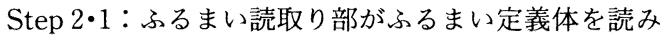
込む.

Step $2 \cdot 2$ ：ふるまい判定部が定義体を解釈し, 設計情 報の継承とともに, 面の幾何デー夕変更時に $\beta$ の面の 変更を促すメッセージを出力する.

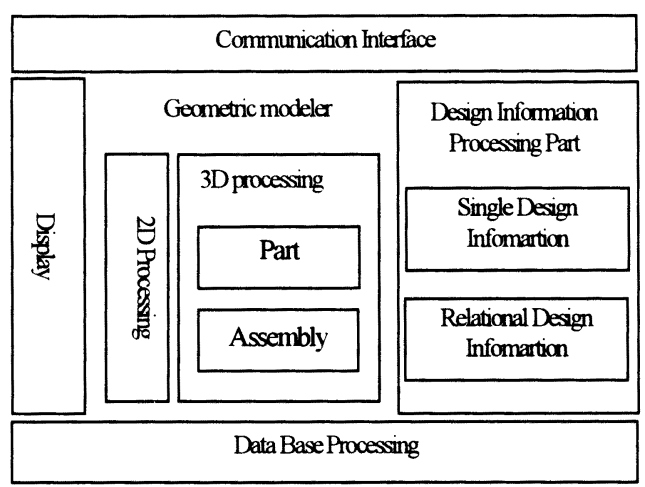

Fig. 10 Components composition chart

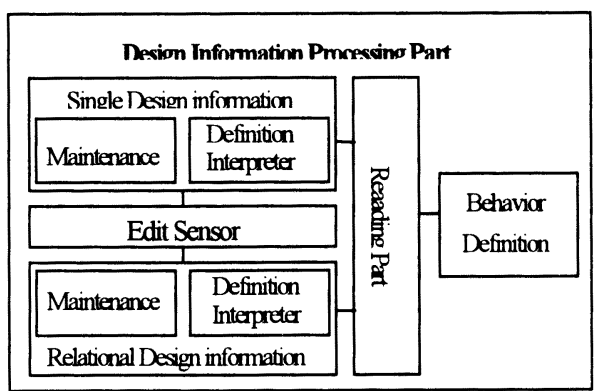

Fig. 11 Sub-components chart of design information processing parts 
システム上で操作が行われた場合に，基本的にすべ ての設計情報が設定されている編集要素に対して，上 記フローの処理が行われることで, 意図を反映した設 計情報伝達，および設計者への注意喚起などが可能に なる。

$4 \cdot 2$ アーキテクチャの特徵まず，本アーキテ クチャは，要件で述べた（a)正確な継承，（b)設計情 報固有のふるまい芫義が可能を満たしており,また後 述する画面例の上うに(c)情報の対象・内签が，でき るだけ直感的にわかりやすくすることが可能である. したがって，基本的な要件を㴻是する.

さらに重要なのは，拢張性の优組みである。表2は， 設計情報の典型的な例を示しているが，設計情報は多 岐にわたるため，情報としては制限なく設定できる必 要がある。また，設計情報の内容に伴い，ふるまい定 義体の内容も抬張可能である必要がある.

本アーキチクチャの楧成要素は, 設計情報・ふるま い定義体・対象・変化種加なる。

拡張性の観点で重要なの灶，こ和ら四つの構成要素 の独方性である。例えば，同じ設計情報に刘して異な るシステムのふるまいが定義できるのは，設計情竍と ふるまい定義体の独立性のためである.同様のこと は，他構成要菜でも可能である。

対象の昖張・設計情報の拡張・ふるまいの拡張など

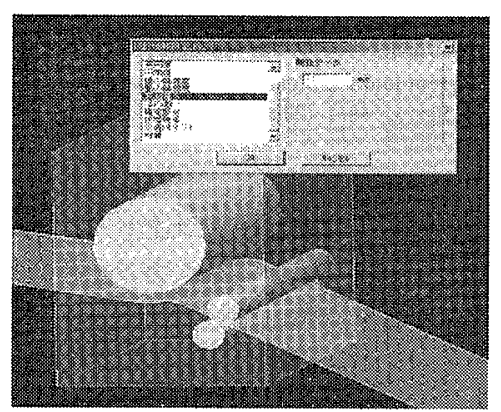

Fig. 12 Setting image of accuracy information

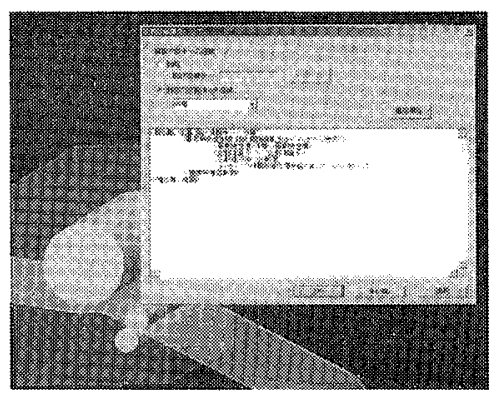

Fig. 13 Setting image of behavior definition
が独立して行えることが，本ア一キテクチャの最も重 要なポイントである。

・対象・設計情報・交るまい・変化種の独立性

・設計情報扔よびるるまい定義体のデータ化

$4 \cdot 3$ 実験システム例 最後に, 設計の流れに沿 った利用例を実驞システムの画面例を用いて述べる.

（1）まず，各設計工程の中で必要な設計情報を設 定していく，設計情報の設定対象の指示および設計情 報入力により設定していく、図 12 は，システムが持 つ精度情報設定画面である、設計情報の典型的な場合 であり，ドラムの表面粗さの設定字行っている画面例 である。

システムがデフォルトで持っているふるまい以外の システム動作・設計情報のふるまいを定義したい場合 は，各設訓情報に対してふるまい定義体を定義するこ とができる。

いま，ドラムに対して，交面粗さと材質の設計情報 が設定され，表面粗さのふるまい定義体に扔いて材質 变更時に, 以下のメッセージ出力“材質が変更きれま した，老面粗さの変更が必要でする定義しておく。

（2）図 13 は，ふるまい定義設定画面例であり，単 体設計情報であるドラムの体積情報制限を表すふるま い定義の設定例である。

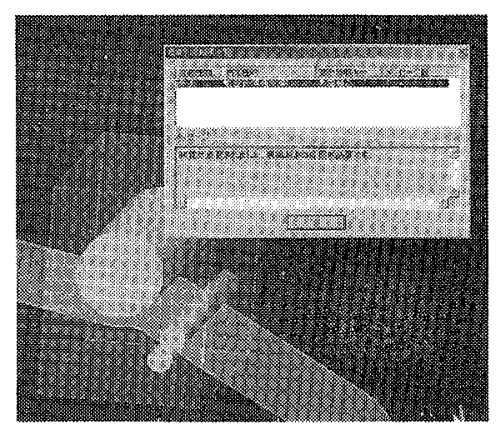

Fig. 14 Example of outputting message

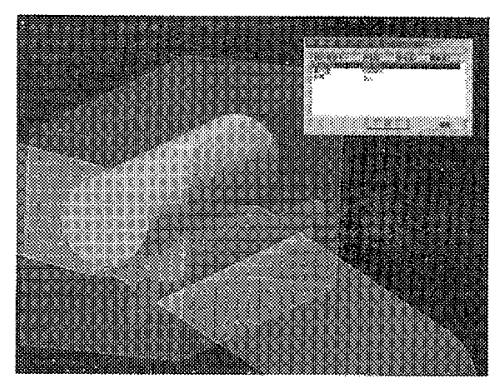

Fig. 15 Output the design information of specified element 
（3）設計が進行していく過程で, 新規のモデル生 成, 既存モデル変更, 構成変更などが行われる.この ような操作の実行時, それ以前の設計の中で定義され ているふるまい定義体(システムのデフォルトを含め て）に従って，設計情報の伝達およびシステムのリア クションが決定される.

（4）図 14 は, ドラムの材質を変更した場合に, 表 面粗さについて注意を喚起するメッセージが出力され た例である.

（5）設計途中での設定した設計情報を確認する手 段として, 設定一覧機能がある. 図 15 は, 指定した幾 何要素に設定されている設計情報一覽の出力画面例で ある。ローラに設計情報として, 表面粗さ, 真円度, 材質が設定されていることを表している.

提案するアーキテクチャでは, 各設計情報の意図・ 意味に応じて, 伝達方法・利用者へのリアクションの 定義が可能である. 本実験例の場合は, 表面粗さ情報 と材質など, 設計情報間の意味を設計情報の伝達の仕 方に反映できることで, 正確な設計情報伝達と設計者 に対して適切な情報を与えることを可能にしている.

\section{5. ま と め}

本論文において，設計プロセスを通じて設計情報・ 意図を伝達していくための統合モデルについて提案し た. 本基本アーキテクチャは, 対象要素とその変化種, および設計情報・ふるまい定義体からなっており, 意 図を反映した正確な設計情報・意図の伝達のふるまい を可能にするのみならず, 意図に応じたシステムのリ アクションのふるまいを可能にしている.
設計情報の抽象性・具体性を問わず, 設計情報・設 計情報間の意味合い・意図を反映できる, 設計情報の 伝達の仕方を制御できる仕組みである。

実際の設計において, 設計情報・意図を正確に下流 設計工程に伝達することは, 設計ミスの削減, 手戻り 削減など効率化に役立つばかりでなく, 計画時の製品 コンセプトの実現にとっても非常に重要な意味を持っ ている。

提案した統合モデルは, 設計の上流から下流まで支 援するアーキテクチャであり, 設計情報・意図を含め た設計プロセス支援の一つの有効な方法論であると考 える。

\section{文献}

（1）吉川弘之・富山哲男監修，インテリジェント $\mathrm{CAD}$ (上), (1989), 朝倉書店.

（2）吉川弘之・富山哲男監修，インテリジェント $\mathrm{CAD}$ (下), (1991), 朝倉書店.

( 3 ) Umeda, Y., Ishii, M., Yoshioka, M., Shimomura, Y. and Tomiyama, T., Supporting Conceptual Design Based on the Function-Behavior-State Modeler, Artif. Intell. Eng. Des., Analysis. Manufact., 10-4 (1996), 275-288.

（4）劉継紅・荒井栄司・井越昌紀, 機械の機能検証のための 定性的運動シミュレーション, 機論, 61-585, C (1995), 2159-2166.

（5）劉継紅・Amnuay，S. - 荒井栄司・井越昌紀, 定性的立体 モデリング（第 1 報, 定性的立体モデルとその構造化）, 機 論, 62-599, C (1996), 2897-2904.

（6）岡田公治・荒井栄司, 機械設計における設計意図モデル に基づく CAD, 機論, 57-544, C (1991), 283-288.

( 7 ) Arai, E., Akasaka, H., Wakamatsu, H. and Shirase, K., Description Model of Designers' Intention in CAD System and Application for Redesign, Proc. JSME Int. J., Ser. C, 43-1 (2000), 177-182. 